\title{
Algoritma K-Means untuk Mengukur Kepuasan Mahasiswa Menggunakan E-Learning
}

\author{
Ratri Enggar Pawening ${ }^{1}$, Fatmawati ${ }^{2}$, Siti Aisyah ${ }^{3}$ \\ 1, 2,3 Program Studi/Jurusan Teknik Informatika, Universitas Nurul Jadid Paiton Probolinggo \\ Email: ratri@unuja.ac.id
}

\begin{abstract}
Abstrak: Penelitian ini bertujuan untuk mengukur kepuasan mahasiswa terhadap pembelajaran daring di Fakultas Teknik Universitas Nurul Jadid. Pandemi COVID-19 mengakibatkan disrupsi atau perubahan besar dalam proses pembelajaran. Fakultas Teknik Universitas Nurul Jadid. Pembelajaran yang dilakukan secara daring memberikan dampak perubahan perilaku dan juga cara mengajar. Hal ini juga berdampak pada tingkat efektifitas dan kepuasan mahasiswa dalam proses pembelajaran. Penelitian ini menggunakan metode deskriptif kualitatif menggunakan KMeans Clustering. Hasil penelititian menunjukkan derajat kepuasan mahasiswa dalam proses belajar mengajar mengalami peningkatan namun tidak signifikan. Hal ini ditunjukkan dengan prosentase respon mahasiswa terhadap penyelenggaraan pembelajaran daring sebesar $80 \%$. Selebihnya menyatakan cukup puas, dan $7 \%$ menyatakan kurang puas dan tidak puas.
\end{abstract}

Kata Kunci: Pembelajaran Daring, K-Means Clustering, Kepuasan

\begin{abstract}
This study aims to measure student satisfaction with online learning at the Faculty of Engineering, Nurul Jadid University. The COVID-19 pandemic has resulted in a major disruption or change in the learning process. Faculty of Engineering, Nurul Jadid University. Online learning has the effect of changing behavior and also the way of teaching. This also has an impact on the effectiveness and satisfaction of students in the learning process. This study uses a qualitative descriptive method using K-Means Clustering. The results showed that the degree of student satisfaction in the teaching and learning process had increased but not significantly. This is indicated by the percentage of student responses to the implementation of online learning by $80 \%$. The rest said they were quite satisfied, and $7 \%$ said they were less satisfied and dissatisfied.
\end{abstract}

Keywords: Online Learning, K-Means Clustering, satisfaction

\section{PENDAHULUAN}

Pembelajaran daring menjadi kebutuhan proses belajar mengajar selama masa pandemi COVID-19. Hal ini tak lepas dari perubahan kebijakan pembelajaran selama pandemi. Beberapa perguruan Tinggi atau Sekolah Tingkat Menengah berupaya maksimal dalam mengimplementasikan pembelajaran daring. Berbagai model pembelajaran daring telah bermunculan dan belum ada satupun penelitian yang menyatakan satu model terbaik. Penelitian yang dilakukan [1] mengungkapkan proses pembelajaran daring menggunakan e-learning cukup efektif untuk mengajarkan Mata Pelajaran Matematika di Sekolah Menengah. Namun hal tersebut tidak serta merta metode ini menjadi sebuah model terbaik. Metode lain yang pernah digunakan adalah dengan menggunakan media chating sebagai sarana komunikasi di kelas. Hal ini telah diteliti oleh [2] yang mengungkapkan bahwa model chating cukup efektif dalam menyampaikan informasi mata kuliah dan tugas lainnya.

Sistem pembelajaran e-learning menjadi tool yang favorit selama masa pandemi. Selain juga untuk pemenuhan kebutuhan, pada dasarnya penerapan $e$ learning ini juga merupakan salah satu perkembangan dalam dunia pembelajaran. Penelitian yang dilakukan [3], [4] menggarisbawahi bahwa penerapan e-learning menjadi sebuah kelaziman di era revolusi industry 4.0. E-learning tidak pernah atau nyaris tidak akan diimplementasikan jika tidak ada sebuah kejadian luar biasa seperti pandemi.

Pembelajaran menggunakan model daring bukan tidak ada kelemahan. Hal ini terkait dengan disparitas akses terhadap e-learning itu sendiri. Kajian [5] menemukan bahwa efektifitas e-learning dalam pembelajaran daring sangat dipengaruhi oleh kemudahan akses maupun pemerataan fasilitas. Namun yang menjadi masalah besar selama masa pembelajaran daring adalah tidak semua peserta didik mempunyai fasilitas yang sama. Hal ini mennimbulkan paritas atau kesenjangan dalam akses pendidikan selama daring. Penelitian [6], [7] mengungkapkan bahwa perlu adanya manajemen e-learning untuk penyelenggaran pembelajaran jarak jauh. Hal ini untuk menjaga dan memastikan informasi pendidikan dan pembelajaran tersampaikan dengan baik.

Sementara itu, beberapa kajian [6], [8]-[10] menegaskan bahwa perlu adanya evaluasi terhadap model pembelajaran daring. Hal ini terkait dengan pengukuran efektifitas dan kepuasan peserta didik selama model pembelajaran daring. Pembelajaran daring membutuhkan evaluasi dalam setiap modelnya untuk mendapatkan metode yang paling sesuai dengan kondisi 
peserta didik atau mahasiswa. Tingkat kepuasan proses pembelajaran telah banyak diteliti oleh berbagai kajian namun pengukuran yang dilakukan terbatas pada media pembelajarannya. Penelitian yang dilakukan oleh [11][13] menyebutkan bahwa penggunaan tools pembelajaran daring masih menjadi fokus utama dalam memberikan evaluasi pembelajaran. Penilaian terhadap model dan perilaku mahasiswa masih belum dilakukan.

Sementara itu, beberapa peneiliti [14]-[17] menekankan perlunya mengkukur pada tingkat efektifitas dan kepuasan peserta didik dalam penyelenggaran pendidikan daring. Beberapa model pembelajaran telah ditawarkan oleh kajian penelitian, namun tidak semua bisa menjadi acuan yang baku, sehingga belum ada sebuah model pembelajaran daring yang dapat diimplementasikan secara universal.

Penelitian ini berfokus pada pengukuran kepuasan peserta didik atau mahasiswa pada penyelenggaran pembelajaran daring. Pengukuran ini dapat menjadi pertimbangan peneliti lain untuk membangun sistem atau model e-learning yang dapat diimplementasikan secara universal.

\section{METODE PENELITIAN}

Penelitian ini menerapkan algoritma K-Means [7] untuk mengelompokkan data ke dalam blok yang berbeda. Langkah-langkah yang diambil adalah sebagai berikut [18]:

1. Menentukan k sebagai clusternya.

2. Menghitung jarak setiap data ke pusat cluster dengan rumus sebagai berikut:

$$
\mathrm{d}_{i k}=\sqrt{\sum_{j}^{m}(C i j-C k j)^{2}}
$$

3. Mengelompokkan data ke cluster yang paling pendek dengan rumus sebagai berikut:

$$
\min \sum_{k=1}^{k} \mathrm{~d}_{i k}=\sqrt{\sum_{j}^{m}(C i j-C k j)^{2}}
$$

4. Menghitung pusat cluster:

$$
C j k=\frac{\sum_{i=1}^{p} x_{i j}}{p}
$$

Xij E adalah kluster ke- $\mathrm{k}$

$\mathrm{P}=$ banyaknya anggota kluster $\mathrm{ke}-\mathrm{k}$

Penjabaran dalam ini juga menggunakan metode deskriptif kuantitatif. Metode ini akan menarasikan dengan lebih detail tetapi tidak digunakan untuk menarik kesimpulan yang lebih luas. Sementara itu, analisis data bersifat induktif/kualitatif. Selain itu, penelitian ini juga menggunakan pendekatan literature review. Data dalam penelitian ini dilakukan dengan melakukan pengamatan langsung di lapangan. Obyek penelitian ini adalah mahasiswa pada Fakultas Teknik Universitas Nurul Jadid. Responden atau narasumber yang digunakan adalah beberapa mahasiswa terkait yang dilakukan dengan menggunakan model wawancara. Metode ini dipilih karena peneliti akan mendeskripsikan keadaan yang diamati secara mendalam, spesifik, dan transparan. Sehingga peneliti dapat memberikan kesimpulan yang fair terkait dengan langkah apa yang harus dilakukan untuk pengebangan pembelajaran daring.

Tahapan K-Menas dalam penelitian ini dapat digambarkan sebaai berikut:

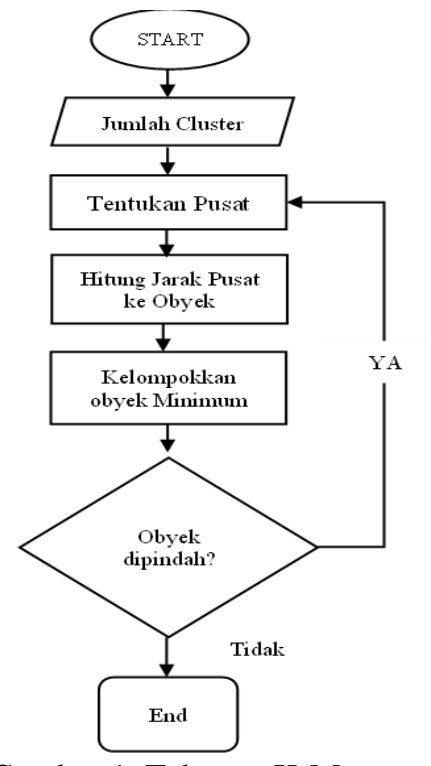

Gambar 1. Tahapan K-Means

Sementara itu konseptual framework dalam penelitian ini adalah sebagai berikut:

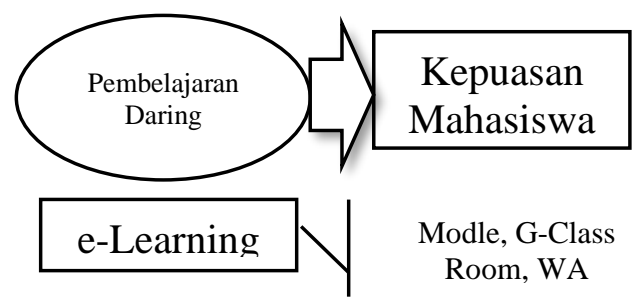

Gambar 2. Konseptual Framework

\section{HASIL DAN PEMBAHASAN}

Berikut ini adalah hasil pemaparan data temuan penelitian. Dalam pemaparan ini terbagi atas 3 (tiga) hal yaitu Deskripsi Data; Model E-learning; dan hasil Pengukuran.

\section{Deskripsi Data}

Penelitian ini menggunakan responden dari pelaku pembelajaran daring. Responden terdiri dari mahasiswa Fakultas Teknik Unuja yang dimabil secara acak sejumlah 100 orang. Berikut ini adalah deskriipsi data penilitian:

Berdasarkan ilustrasi pada Gambar 3 di atas menunjukkan bahwa dari 100 responden jumlah laki-laki dan perempuan nyaris seimbang bahkan mempunyai kecenderungan dari sisi gender, responden lebih banyak perempuan. Sementara itu, dari sisi media yang digunakan dalam proses pembelajaran, peserta didik lebih banyak menggunakan HandPhone dibandingkan 
Laptop. Hal ini menunjukkan perilaku mobile pada mahasiswa lebih tinggi. Penggunaan handphone (HP) sebagai salah satu perangkat utama dalam pembelajaran menjadi trend di masa pandemi. Hal ini senada dengan penelitian [19] yang mengemukakan bahwa penggunaan HP untuk pembelajaran lebih masif jika dibandingkan dengan laptop. Kondisi ini hendaknya bisa disikapi oleh penyelenggara pendidikan daring untuk membangun aplikasi pembelajaran daring yang lebih support ke sistem Android atau IoS. Hal senada juga diungkapkan oleh penelitian [20]-[22] yang mengungkapkan bahwa pendidikan daring menjadi kebutuhan di masa pandemi, namun yang lebih penting dari itu adalah aplikasi pembelajaran daring harus mampu diakomodasi oleh semua perangkat termasuk handphone.

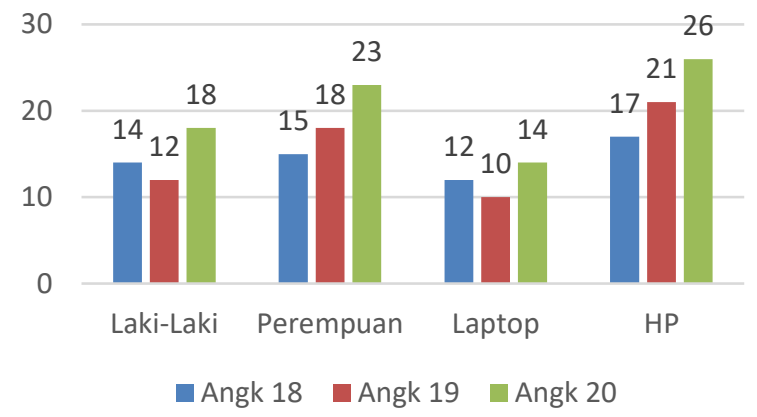

Gambar 3. Deskripsi Data Responden

Dari sisi perangkat yang digunakan, jika ditinjau dari aplikasi, beberapa peranggkat terutama HandPhone tidak mendukung $100 \%$ fitur yang ada dalam e-learning. Sehingga peserta didik (mahasiswa) harus melalukan penyesuaian pada perangkatnya. Hasil temuan empiris ini bisa digunakan sebagai stimulus pengambilan keputusan atas pengembangan aplikasi e-learning. Penelitian yang dilakukan [8], [23] menunjukkan bahwa selain fokus pada aplikasi yang digunakan, maka fokus lain yang tidak kalah penting adalah aplikasi tersebut harus support dengan perangkat mobile.

Data pada Gambar 3 di atas juga menunjukkan bahwa ada 64 dari 100 mahasiswa menggunakna HP untuk mengakses $e$-learning. Sebagian dari mahasiswa tersebut menyatakan kesulitan untuk mengakses e-learning. Kesulitan ini terkait dengan perangkat yang kurang support dengan aplikasi tersebut. Sebaliknya ada beberapa mahasiswa juga menyatakan bahwa aplikasi $e$ learning yang tidak support. Pada Gambar 4 adalah data empiris responden terhadap perangkat yang digunakan.

Berdasarkan grafik pada Gambar 4 di atas menunjukkan bahwa sebagian besar dari pengguna HP untuk pembelajaran pernah mengakses e-learning. Sementara itu $75 \%$ atau sejumlah 48 orang menyatakan aplikasi e-learning mendukung diakses menggunakan HP. Sisanya atau $25 \%$ menyatakan tidak mendukung.

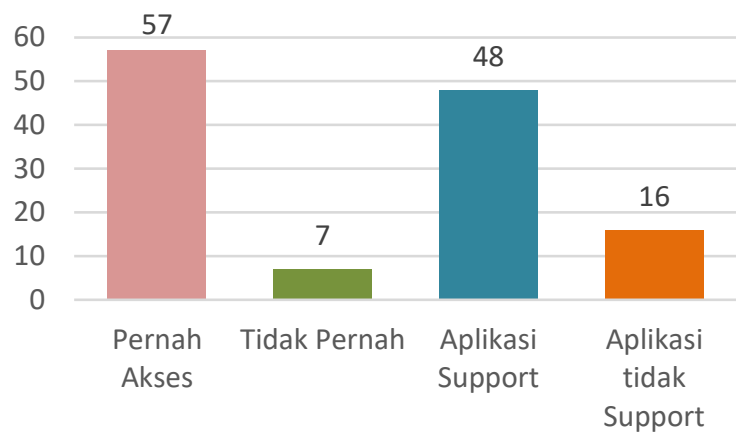

Gambar 4. Mahasiswa Mengakses Menggunakan HP

\section{Model E-learning}

E-learning yang digunakan pada obyek penelitian ini berbasis modle. Modle telah dikembangkan dan dipergunakan oleh penyelenggaran pembelajaran online di berbagai negara. Model ini menjadi model stándar dan baku yang digunakan oleh institusi pendidikan selain google classroom. Salah satu kunggulan dari model ini adalah fitur lengkap yang memungkinkan pembelajaran dialihkan ke daring. Komponen pembelajaran mulai dari aktifitas classical, tugas, presensi, interaksi dalam bentuk diskusi semua disediakan oleh aplikasi tersebut.

Aplikasi ini dapat berjalan nyaris di semua platform baik Android, IoS, maupun windows selama terhubung dengan jaringan internet. Seperti yang telah dijelaskan pada latar belakang di atas, salah satu paritas atau kesenjangan dalam penerapan e-learning tersebut adalah akses jaringan internet yang tidak sama. Sehingga pesan yang disampaikan dari penyelenggara pendidikan tidak tersampaikan dengan baik. Dari sisi fitur aplikasi, modle ini telah memenuhi syarat digunakan untuk perangkat pembelajaran. Hal ini dikuatkah oleh [24], [25] di mana penggunaan modle sebagai media pembelajaran semakin masif. Hal ini tidak lepas dari fitur yang diberikan oleh modle itu sendiri. Ilustrasi pada Gambar 5 menunjukkan begitu kompleksnya kompleksnya aplikasi modle.

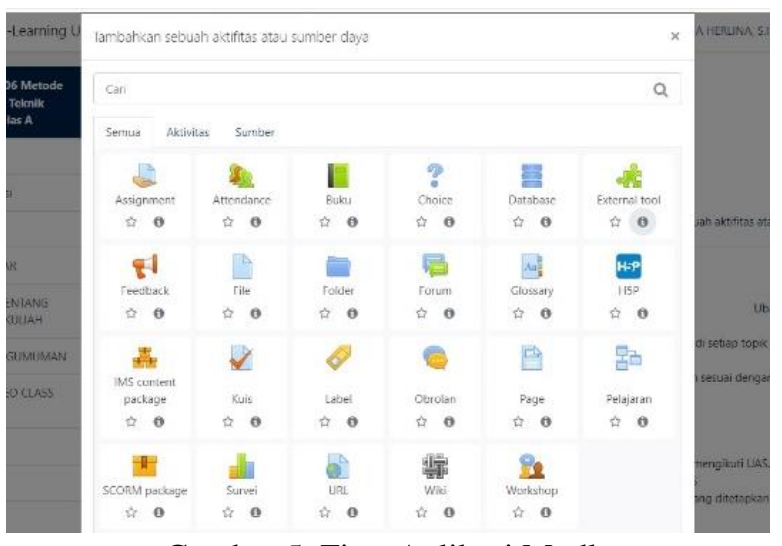

Gambar 5. Fitur Aplikasi Modle

Ilustrasi pada Gambar 5 menunjukkan bahwa nyaris semua aktifitas pembelajaran dapat diakomodasi oleh aplikasi tersebut. Fitur tersebut menawarkan mulai 
dari resources (sumber materi pembelajaran), video multimedia, aktifitas tugas, penilaian, sampai dengan presensi siswa.

Di sisi lain, kompleksitas aplikasi ini harus dibayar mahal dengan load yang cukup berat ketika mengaksesnya. Sehingga perangkat (HP atau laptop) dengan kemampuan di bawah rata-rata akan kesulitan mengakses informasi tersebut. Temuan empiris ini menjawab pertanyaan pada latar belakang di atas, bahwa kecepatan akses aplikasi tersebut bukan hanya terletak pada kesiapkan software, tetapi juga hardware.

Selain kelemahan aplikasi ini dari sisi load, aplikasi ini mempunyai sekuritas yang cukup memadai. Hal ini ditunjukkan dengan proses akses aplikasi ini diharuskan menggunakan akun yang telah terverifikasi.
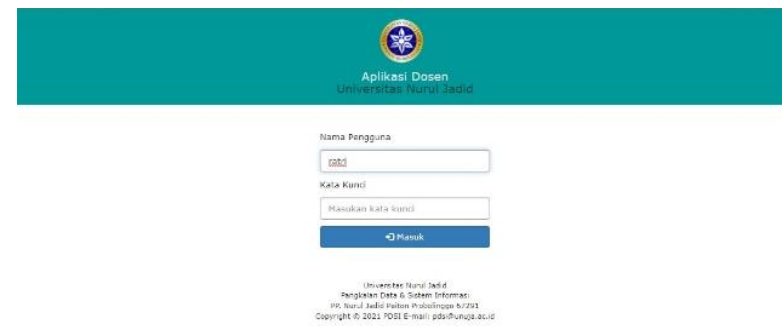

\section{Gambar 4 Halaman Pertama Login}

Ilustrasi pada Gambar 6 menunjukkan bahwa setiap anggota pembelajar yang akan menggunakan aplikasi ini harus mempunyai akun yang telah terverifikasi pada sistem. Hal ini untuk menghindari pihak kedua yang tidak mempunyai hak akses dapat masuk pada sistem. Sekuritas ini menjadi pengamanan standar pada sebuan Learning Management System (LMS). Sehingga dari sisi kemanan, aplikasi ini cukup aman digunakan.

Selain sekuritas aplikasi tersebut, aplikasi ini memberikan pilihan clustre dalam bentuk sub menu. Sub menu ini untuk memberikan kenyamanan dan kemudahan pengguna. Hal ini terkait dengan fitur yang sangat kompleks yang ditawarkan oleh modle sehingga pengguna membutuhkan menu yang dibagi per cluster.
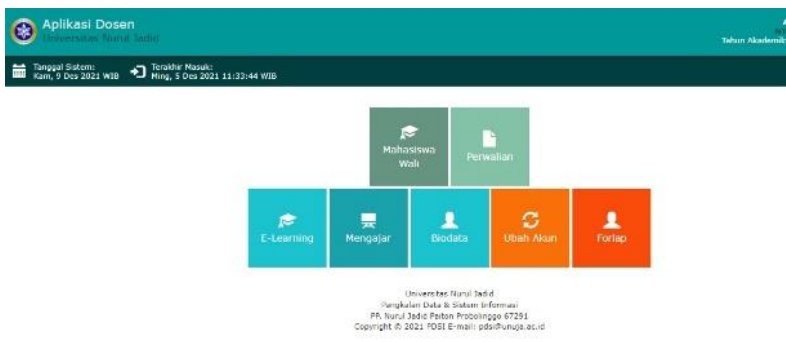

Gambar 7. Cluster Menu

Ilustrasi pada Gambar 7 menunjukkan bahwa kemudahan aplikasi ini ditunjukkan dengan memberikan cluster menu. Kemudahan dalam penggunaan aplikasi ini adalah salah satu syarat untuk membangun kepuasan pengguna. Penelitian yang dilakukan oleh [26]-[28] menunjukkan bahwa kemudahan penggunaan menjadi salah satu indikasi kepuasan pengguna website ( $e$ learning). Sehingga kemudahan ini menjadikan salah satu kunggulan aplikasi tersebut.

\section{Hasil Pengukuran}

Penelitian ini mengukur kepuasan peserta didik (mahasiswa) terhadap penyelenggaran pembelajaran daring. Tahapan pengukuran diawali sebagai berikut:

\section{Pengumpulan data}

Pada tahap ini peneliti mengambil data yang dilakukan secara daring. Pengambilan data secara daring tersebut karena menerapkan aturan protokol kesehatan. Kuesioner diberikan dalam bentuk link google forms. Tahap pengumpulan data tersebut kemudian ditabulasikan dan dhitung mengggunakan K-Means.

\section{Pengolahan Data}

Pada tahap ini responden yang mengisi data dikelompokkan ke dalam kriteria. Deskripsi data dapat dilihat pada Tabel 1 .

Tabel 1. Tanggapan Responden

\begin{tabular}{|c|c|c|c|}
\hline No. & Responden & & nggapan \\
\hline & & Setuju & Tidak Setuju \\
\hline 1. & Res. 01 & 9 & 1 \\
\hline 2. & Res. 02 & 4 & 6 \\
\hline 3. & Res. 03 & 6 & 4 \\
\hline 4. & Res. 04 & 5 & 5 \\
\hline 5. & Res. 05 & 7 & 3 \\
\hline 6. & Res. 06 & 8 & 2 \\
\hline 7. & Res. 07 & 3 & 7 \\
\hline 8. & Res. 08 & 5 & 5 \\
\hline 9. & Res. 09 & 9 & 1 \\
\hline 10. & Res. 10 & 7 & 3 \\
\hline 11. & Res. 11 & 8 & 2 \\
\hline 12. & Res. 12 & 6 & 4 \\
\hline 13. & Res. 13 & 9 & 1 \\
\hline 14. & Res. 14 & 9 & 1 \\
\hline 15. & Res. 15 & 9 & 1 \\
\hline 16. & Res. 16 & 8 & 2 \\
\hline 17. & Res. 17 & 10 & 0 \\
\hline 18. & Res. 18 & 8 & 2 \\
\hline 19. & Res. 19 & 9 & 1 \\
\hline 20. & Res. 20 & 7 & 3 \\
\hline 21. & Res. 21 & 6 & 4 \\
\hline 22. & Res. 22 & 8 & 2 \\
\hline 23. & Res. 23 & 9 & 1 \\
\hline 24. & Res. 24 & 5 & 5 \\
\hline 25. & Res. 25 & 7 & 3 \\
\hline
\end{tabular}

Berdasarkan data tanggapan responden pada tabel 1 di atas menunjukkan kecnderungan responden memberikan indikasi kepuasan. Kepuasan yang ditunjukkan pada table 1 di atas belum merupakan kesimpulan akhir, namun indikasi pada kepuasan sudah 
nampak. Maka perlu dilakukan pengukuran pada tahap lanjutan yaitu menghitung tingkat sensitifitas. Hasil pengukuran tingkat sensitifitas ditunjukkan pada tabel 2.

Tabel 1. Algoritma K-Means

\begin{tabular}{lll}
\hline \multirow{4}{*}{ Tinggi/Puas } & Jumlah & $\begin{array}{l}\text { Algoritma } \\
\text { K-Means }\end{array}$ \\
\hline & Tangible & 199 \\
\cline { 2 - 3 } & Reliability & 201 \\
\cline { 2 - 3 } & Responsiveness & 213 \\
\cline { 2 - 3 } & Assurance & 178 \\
\cline { 2 - 3 } Rendah/Tidak & Empathy & 189 \\
\hline Puas & Tangibel & 43 \\
\cline { 2 - 3 } & Reliability & 55 \\
\cline { 2 - 3 } & Responsiveness & 23 \\
\cline { 2 - 3 } & Assurance & 34 \\
\cline { 2 - 3 } & Empathy & 12 \\
\hline
\end{tabular}

Berdasarkan Tabel 2 menunjukkan bahwa nilai tangible tinggi/puas berada pada 199 poin dan tangible rendah/tidak puas pada poin 43. Sementara itu nilai reliability tinggi/puas berada pada 201 poin dan reliability rendah/tidak puas pada 55 poin. Hal ini menunjukkan berdasarkan nilai Algoritma K-Means derajat kepuasan mahasiswa terhadap penyelenggaraan pembelajaran daring lebih tinggi dibandingkan dengan derajat tidak puas.

Selain itu, hasil pada Tabel 2 di atas menegaskan kembali penelitian yang dilakukan [4], [7] bahwa pembelajaran daring menggunakan aplikasi modle memberikan kepuasan terhadap mahasiswa. Sementara itu, penelitian ini juga mengukur tingkat kepuasan berdasarkan nilai sensitifitas Algoritma KMeans. Hasil pengujian menunjukkan fakta sebagai berikut:

Tabel 3. Pengujian Sesitifitas K-Means Jumlah Algoritma K-Means

\begin{tabular}{llc}
\hline & Jumlah & $\begin{array}{c}\text { Algoritma } \\
\text { K-Means }\end{array}$ \\
\hline \multirow{5}{*}{ Sensitifitas } & Tangible & $80 \%$ \\
\cline { 2 - 3 } & Reliability & $77 \%$ \\
\cline { 2 - 3 } & Responsiveness & $89 \%$ \\
\cline { 2 - 3 } & Assurance & $75 \%$ \\
\cline { 2 - 3 } Spesifisitas & Empathy & $76 \%$ \\
\cline { 2 - 3 } & Tangibel & $23 \%$ \\
\cline { 2 - 3 } & Reliability & $15 \%$ \\
\cline { 2 - 3 } & Responsiveness & $17 \%$ \\
\cline { 2 - 3 } & Assurance & $12 \%$ \\
\hline & Empathy & $7 \%$ \\
\hline
\end{tabular}

Berdasarkan data pada tabel 3 di atas menunjukkan bahwa tangible mempunyai nilai sensitifitas yang cukup tinggi yaitu $80 \%$, responsiveness $89 \%$. Nilai sensitifitas lainnya berada pada rentang 70an\%. Hal ini menunjukkan bahwa nilai kepuasan mahasiswa dalam pembelajaran daring cukup tinggi. Meskipun mereka ada kendala dengan perangkat, namun kultur akademik daring tersebut ternyata cukup memberikan kepuasan mahasiswa. Nilai kepuasan yang cukup tinggi tersebut sejalan dengan penelitian [29] yang mengungkapkan efektifitas perangkat daring memberikan kepuasan peserta didik.

Penelitian inin sekaligus memberikan kontra terhadap apa yang diteliti oleh [30], [31] yang menegaskan bahwa kepuasan mahasiswa tidak hanya dipengaruhi oleh perangkat dan aplikasi, lebih jauh dari itu adalah mereka menekankan pada aspek psikologis mahasiswa pada masa pandemi.

\section{KESIMPULAN DAN SARAN}

Penelitian ini menemukan bahwa kepuasan mahasiswa selama penyelenggaraan pendidikan daring cukup tinggi. Meskipun ada beberapa mahasiswa yang mengalami kesulitan dalam mengkases aplikasi selama daring, manum pada dasarnya masalah lebih banyak karena hardware yang tidak atau kurang mendukung.

Penelitian ini juga menemukan bahwa sebagian dari peserta didik atau mahasiswa yang tidak dapat mengakses aplikasi karena sebagian aplikasi tidak support terhadap hardware yang dimiliki mahasiswa. Sehingga hal ini menjadi peluang penelitian lanjutan untuk mengembangkan sistem atai aplikasi e-learning yang mampu support kepada perangkat secara universal.

Penelitian ini juga mempunyai keterbatasan pada lingkup obyek penelitian yang hanya berfokus pada satu perguruan tinggi. Sehingga generalisasi atas temuan dalam penelitian ini belum berlaku secara kesuluruhan. Artinya, temuan dalam penelitian ini belum bisa dijadikan generalisasi secara umum atau menjadi fenomena baru dalam dunia pendidikan. Sehingga penelitian ini memberikan ruang baru bagi peneliti lain untuk melakukan penelitian lanjutan terkait dengan pengembangan aplikasi e-learning yang dapat diaplikasikan ke semua perangkat secara universal.

\section{DAFTAR PUSTAKA}

[1] V. A. Anggraini, N. Mauliska, and M. Sholehah, "Pembelajaran Daring Mahasiswa Tadris Matematika dengan Menerapkan ELearning di Tengah Pandemi Covid-19," Kulidawa, vol. 1, no. 2, pp. 61-64, 2020.

[2] D. C. Y. Putri, "Perkuliahan Daring di Masa Pandemi Covid-19," J. PTK dan Pendidik., vol. 6, no. 2, 2021, doi: 10.18592/ptk.v6i2.4151.

[3] B. Indrayana and A. Sadikin, "Penerapan ELearning Di Era Revolusi Industri 4.0 Untuk Menekan Penyebaran Covid-19," Indones. J. Sport Sci. Coach., vol. 2, no. 1, pp. 46-55, 2020, doi: 10.22437/ijssc.v2i1.9847.

[4] A. P. Nanda, D. Eko, and H. Pramono, "Menentukan Tingkat Kepuasan Mahasiswa Terhadap Pelayanan Akademik Menggunakan,” J. Sist. Inf. dan Telemat., vol. 11, no. 1, pp. 23-28, 2020.

[5] N. Kholipah, D. Arisanty, and K. P. Hastuti, "Efektivitas Penggunaan E-Learning dalam Pembelajaran Daring Selama Masa Pandemi 
COVID-19," JPG (Jurnal Pendidik. Geogr., vol. 7, no. 2, pp. 24-33, 2021, doi: 10.20527/jpg.v7i2.10206.

[6] U. Fatonah and R. Mulyono, "Manajemen ELearning Dalam Pembelajaran Jarak Jauh," Media Manaj. Pendidik., vol. 4, no. 1, pp. 150159, 2021

[7] K. D. R. Sianipar, S. W. Siahaan, M. Siregar, and P. P. P. A. N. W. F. I. R. H. Zer, "Penerapan Algoritma K-Means Dalam Menentukan Tingkat Kepuasan Mahasiswa Terhadap Pembelajaran Online," Infomatek, vol. 22, no. 1, pp. 23-30, 2020, doi: 10.23969/infomatek.v22i1.2748.

[8] H. D. Herman Dwi, "The Evaluation of a Moodle Based Adaptive e-Learning System," Int. J. Inf. Educ. Technol., vol. 4, no. 1, pp. 8992, 2014, doi: 10.7763/ijiet.2014.v4.375.

[9] E. Pakpahan, "Efektivitas Penerapan ELearning Selama Pandemi Covid-19," J. Ilm. Akunt. dan Bisnis, vol. 1, no. 2, pp. 72-87, 2021.

[10] K. S. Prikhodko, E. N. Danilevskaya, K. S. Savina, and R. E. Shupenko, "Innovative opportunities and reserves of contemporary marketing communication," Int. J. Econ. Bus. Adm., vol. 7, 2019, doi: 10.35808/ijeba/293.

[11] A. Al-Azawei, W. R. Baiee, and M. A. Mohammed, "Learners' experience towards eassessment tools: A comparative study on virtual reality and moodle quiz," Int. J. Emerg. Technol. Learn., vol. 14, no. 5, pp. 34-50, 2019, doi: 10.3991/ijet.v14i05.9998.

[12] M. J. Rubio, "Focus and models of evaluation of the e-learning," Reli. - Rev. Electron. Investig. y Eval. Educ., vol. 9, no. 2, pp. 101120, 2003, doi: 10.7203/relieve.9.2.4332.

[13] D. Kurnia, "Penerimaan dan Penggunaan ELearning pada Masa Pandemi Covid-19: Aplikasi Model UTAUT2," JKTP J. Kaji. Teknol. Pendidik., vol. 3, no. 4, pp. 435-447, 2020, doi: 10.17977/um038v3i42020p435.

[14] H. B. Seta, T. Wati, A. Muliawati, and A. N. Hidayanto, "E-learning success model: An extention of delone \& mclean is' success model," Indones. J. Electr. Eng. Informatics, vol. 6, no. 3, p. 281 291, 2018, doi: 10.11591/ijeei.v6i3.505.

[15] A. Rahman Ahmad, V. A/P Govinda Raj Segaran, and H. Rizad Md Sapry, "Academic Staff and Industry Revolution 4.0: Knowledge, Innovation and Learning Factor," J. Educ. eLearning Res., vol. 7, no. 2, pp. 190-194, 2020 , doi: 10.20448/journal.509.2020.72.190.194.

[16] N. K. Suryani and I. A. P. W. Sugianingrat, "Student E-Learning Satisfaction During The Covid-19 Pandemic in Bali, Indonesia," J. Econ., vol. 17, no. 1, pp. 141-151, 2021, doi: 10.21831/economia.v17i1.33196.
[17] M. H. Fakhriza, "Comparison Of K-Means Method And Fuzzy Clustering Algorithm In Determining Customer Satisfaction Test In Delivery Services," JIKA (Jurnal Inform., vol. 5, no. 2, 2021, doi: 10.31000/jika.v5i2.4511.

[18] H. Zare and S. Emadi, "Determination of Customer Satisfaction using Improved Kmeans algorithm," Soft Comput., vol. 24, no. 22, 2020, doi: 10.1007/s00500-020-04988-4.

[19] N. Tuaycharoen, "University-Wide Online Learning During COVID-19: From Policy to Practice," Int. J. Interact. Mob. Technol., vol. 15, no. 2, pp. 38-54, 2021, doi: 10.3991/ijim.v15i02.18143.

[21] R. Firmansyah, D. M. Putri, M. G. S. Wicaksono, S. F. Putri, A. A. Widianto, and M. R. Palil, "Educational Transformation: An Evaluation of Online Learning Due to COVID19, ’ Int. J. Emerg. Technol. Learn., vol. 16, no. 7, pp. 61-76, 2021, doi: 10.3991/ijet.v16i07.21201.

[22] U. A. Chaeruman, B. Wibawa, and Z. Syahrial, "Development of an instructional system design model as a guideline for lecturers in creating a course using blended learning approach,” Int. J. Interact. Mob. Technol., vol. 14, no. 14, pp. 164-181, 2020, doi: 10.3991/ijim.v14i14.14411.

[23] L. Lorenza and D. Carter, "Emergency online teaching during COVID-19: A case study of Australian tertiary students in teacher education and creative arts," Int. J. Educ. Res. Open, vol. 2-2, Jan. 2021, doi: 10.1016/j.ijedro.2021.100057.

[24] H. N. Sabeh, M. H. Husin, D. M. H. Kee, A. S. Baharudin, and R. Abdullah, "A Systematic Review of the DeLone and McLean Model of Information Systems Success in an E-Learning Context (2010-2020)," IEEE Access, vol. 9, pp. 81210-81235, 2021, doi: 10.1109/ACCESS.2021.3084815.

[25] M. J. D. Sunarto, "The Readiness of Lecturers in Online Learning During the Covid-19 Pandemic at the Faculty of Information Technology and the Faculty of Economics and Business," IJORER Int. J. Recent Educ. Res., vol. 2, no. 1, pp. 54-64, 2021, doi: 10.46245/ijorer.v2i1.70.

[26] F. D. S. Sumantyo, "Pendidikan Tinggi di Masa dan Pasca Covid-19," J. Kaji. Ilm., vol. 1, no. 1, pp. 81-92, 2020, doi: 10.31599/jki.v1i1.266.

[27] M. L. Jundillah, J. E. Suseno, and B. Surarso, "Evaluation of E-learning Websites Using the Webqual Method and Importance Performance Analysis," vol. 01, no. 201 9, pp. 1-5, 2019.

[28] S. Sucipto, "Measurement e-commerce Services Quality: Applying Webqual 4.0 and Importance Performance Analysis," J. 
Comput. Sci. Eng., vol. 2, no. 1, pp. 70-79, 2021, doi: 10.36596/jcse.v1i2.26.

[29] Ismail and F. P. Al-Bahri, "WebQual 4 . 0 dan Importance-Performance Analysis (IPA) : Eksplorasi Kualitas Situs Web e-Kuisioner," J. JTIK (Jurnal Teknol. Inf. dan Komunikasi), vol. 3, no. 2, pp. 52-58, 2019.

[30] W. Lu, S. M. Mustapha, and N. Abdullah, "Constructing and Validating University Students' Blended Learning Acceptance Scale,” Int. J. Interact. Mob. Technol., vol. 15, no. 4, pp. 101-108, 2021, doi: 10.3991/IJIM.V15I04.20195.

[31] E. Gonçalves and L. Capucha, "Studentcentered and ICT-enabled learning models in veterinarian programs: What changed with COVID-19?," Educ. Sci., vol. 10, no. 11, pp. 1-17, 2020, doi: 10.3390/educsci10110343. 